\title{
OCORRENCE OF MISCHOCYTTARUS ROTUNDICOLLIS (VESPIDAE) IN MANGROVE SWAMPS ATTRACTED BY FISH IN DECOMPOSITION
}

\author{
${ }^{1,2}$ Jose Antonio Batista-Da-Silva and ${ }^{2}$ Antonio Edesio Almeida de Souza \\ ${ }^{1}$ Laboratório de Educação em Ambiente e Saúde (Instituto Oswaldo Cruz- IOC/FIOCRUZ), \\ Av. Brasil, 4365, Manguinhos (R.J.), Brazil \\ ${ }^{2}$ Programa Saúde na Escola, SEMEC (Secretaria Municipal de Educação e Cultura), \\ Prefeiturea Municipal de Itaboraí (RJ), Brazil
}

Received 2013-11-25; Revised 2013-12-02; Accepted 2013-12-07

\begin{abstract}
Vespidae is an important insect family that is among the largest predators of other insects in natural environments. This study in mangrove swamps was carried out in order to know if social wasp, Mischocyttarus (Mischocyttarus) rotundicollis could be attracted by fish (sardine) in decomposition. The insects were collected in mangrove swamps in Itaborai, every two weeks, totaling 72 samples from August 2008 to July 2011. Over a 36 months period 69 individuals were caught. The abiotic factors (season and tidal variations) that could influence the occurrence of these wasps in mangrove swamps were recorded. The abundance of wasps was only affected by the spring season and the highest tides (spring-tides). The presence of the $M$. rotundicollis, in the mangrove swamps caught with fish in decomposition, may indicate that the studied forest area still represents a natural preserved refuge and reveals the importance of understanding of ecology these wasps and provides much information that will contribute greatly to environmental sciences.
\end{abstract}

Keywords: Abiotic Factors, APA De Guapi-Mirim, Social Wasp

\section{INTRODUCTION}

Among all the Brazilian ecosystems, the mangrove swamp is perhaps the most impacted, due to intense human interference. On one hand, despite the security measures, the illegal activities of hunting and fishing as well as hunting crabs with loop closures is a part of the problem and on the other hand there are large amounts of sewage, industrial and agricultural wastes being discharged into mangrove swamps (Kamaruzzaman et al., 2008). These two impacts have caused physical changes to the swamp environment (Gandaseca et al., 2011) and caused the death of many endemic species or changes in the structure of invertebrate colonies (Johnston and Keough, 2002).

Vespidae is an important insect family that is included in the order Hymenoptera and is among the largest predators of other insects in natural environments. This family has approximately 4,600 species and is divided in six subfamilies: Eumeninae, Masarinae, Euparagiinae, Stenogastrinae, Vespinae and Polistinae (Carpenter, 1981). According to Carpenter (2004) twenty five genera of Polistinae are known and twenty one can be found in the Neotropics and the social wasps produce a paper-like substance by mastication of vegetation to build their nests (Gallo et al., 1988).

Henrique-Simoes et al. (2011) reported the lack of studies of social wasps in several Brazilian ecosystems, which makes it more difficult to understand the distribution and biology of these insects.

This study of wasp Mischocyttarus rotundicollis in the mangrove swamps of Itaboraí (RJ) was carried out in order to know if this species could be attracted by fish (sardine) in decomposition in the Guapi-Mirim IOC/FIOCRUZ), Av. Brasil, 4365, Manguinhos (R.J.), Brazil 
Environmental Protection Area (APA de Guapi-Mirim) in Itaboraí in each season and tidal variations. There are no studies showing this type of bait as attractive for this species, which increases the need for this study.

\section{MATERIALS AND METHODS}

The insects were collected in mangrove swamps in Itaboraí. Its geographical location is S $22^{\circ} 39^{\prime} 30^{\prime \prime}-22^{\circ}$ 46' 50" latitude and W $42^{\circ} 57^{\prime} 00^{\prime}$ '- $43^{\circ} 06^{\prime} 40^{\prime \prime}$ longitude in Rio de Janeiro state, Brazil. Collections were performed every two weeks, totaling 72 samples from August 2008 to July 2011. To collect the wasps, four 35 $\mathrm{cm}$ high and $15 \mathrm{~cm}$ diameter plastic traps placed $100 \mathrm{~m}$ apart were used. The traps were suspended at a height of $1.20 \mathrm{~m}$ above the ground for a period of $48 \mathrm{~h}$ and the bait was sardine in decomposition (traps and methodology according to Ferreira, 1978 and modified according to Batista-da-Silva et al., 2010).

All insects caught were killed by asphyxiation inside the trap, with $70 \%$ ethanol and were put into plastic pots with $70 \%$ ethanol. All wasps were identified using a stereoscopic microscope and the dichotomous keys for species according to (Carpenter, 2004; Hermes and Kohler, 2004).

The average temperatures and average humidity through satellite data (INPE, 2008) in each season and tidal variations $(\mathrm{BN}, 2011)$ as well as the standard deviation for the same data were recorded.

\section{RESULTS}

Over 36 months, 69 females of this social wasp belonging to the species Mischocyttarus (Mischocyttarus) rotundicollis (Cameron, 1974) were caught.

The average temperature during the period was $30.34 \pm 4.57^{\circ} \mathrm{C}$ and the average humidity was $65.32 \pm 10.80 \%$.

\section{DISCUSSION}

Wasps can be found in several environments, among them, the Amazonian forest, Pantanal and the Atlantic Rain Forest in Brazil (Carpenter and Marques, 2001) but the social wasp distribution in other Brazilian ecosystems has not been very well documented, mainly in mangrove swamps along the Brazilian coast.

The use of sugary substance is most commonly used method to capture wasps. Noll and Gomes (2009) used an attracting liquid, a solution of sucrose and repeated by Junior and Noll (2011) where the number of individuals of the species $M$. rotundicollis caught in a preserved area, in Matão, São Paulo, Brazil, was only 2 wasps. In this study was used as bait, sardines in decomposition because it had not been used previously, being more efficient than a solution of sucrose.

Santos et al. (2007) studied the diversity of social wasps in three different ecosystems: mangrove swamp, the Atlantic Rain Forest and on Itaparica Island, Bahia, Brazil; but did not catch $M$. rotundicollis in the mangrove swamp.

Abiotic factors such as tides and salinity (contains a salt concentration of approximately only $13 \%$ in mangrove swamps) are importance because they have a evident influence on the marine environment (Santos et al., 2007). This may have provided the species $M$. rotundicollis a competitive advantage over other forest social wasps for food resources in relation to other species of social wasps, because no other species were caught with sardines in decomposition in mangrove swamps in Guapi-Mirim Environmental Protection Area, in Itaboraí.

According to Batista-da-Silva (2012) spring and summer has the highest tides in the mangrove swamp $(1.40 \mathrm{~m})$ and these abiotic factors may influence the occurrence of insects of the family Calliphoridae and Phoridae in mangrove. It is possible that these abiotic factors (tides and seasons) also influence the occurrence of $M$. rotundicollis, because the insect larvae are more abundant in mangrove swamps when the tides reached their highest levels in spring (Table 1). This fact may be due to the synchronism between the biological cycle of the insects, with the abiotic factors cited (tides, seasons and salinity) and a greater availability of food resources in spring, mainly insect larvae.

Table 1. Seasons of the year and tidal variations in meters in the mangrove swamp area, according to data provided by the BN (2011) and number of wasps captured from August 2008 to July 2011, Itaboraí, Rio de Janeiro, Brazil

\begin{tabular}{llllc}
\hline Seasons & $\begin{array}{l}\text { Low tides } \\
(\mathrm{m})\end{array}$ & $\begin{array}{l}\text { High tides } \\
(\mathrm{m})\end{array}$ & $\begin{array}{l}\text { Individuals } \\
(\mathrm{n})\end{array}$ & $\begin{array}{l}\text { Individuals } \\
(\%)\end{array}$ \\
\hline Spring & $0.0-0.40$ & $0.90-1.30$ & 31 & 44.92 \\
Summer & $0.0-0.50$ & $0.90-1.50$ & 11 & 15.94 \\
Autumn & $0.0-0.50$ & $1.00-1.40$ & 05 & 7.25 \\
Winter & $0.0-0.50$ & $0.70-1.30$ & 22 & 31.89 \\
Total & - & - & 69 & 100.00 \\
\hline
\end{tabular}




\section{CONCLUSION}

The presence of the social wasp $M$. rotundicollis, in the mangrove swamps in this study may indicate that the studied forest area still represents a natural preserved refuge. Knowledge of the behavior of this specie (caught with fish in decomposition) related to certain abiotic factors such as tides, seasons and salinity, reveals the importance of understanding of ecology these wasps and provides much information that will contribute greatly to environmental sciences.

\section{ACKNOWLEDGMENT}

To Escola Municipal Marly Cid Almeida de Abreu for financial support, to the board of the Área de Proteção Ambiental de Guapi-Mirim (APA GuapiMirim) that granted permission to collect the specimens and David Graham Straker for the English revision.

\section{REFERENCES}

Batista-da-Silva, J.A., 2012. Phoretic association and facultative parasitoidism between Megaselia scalaris and blowflies, under natural conditions. OnLine J. Biol. Sci., 12: 34-37. DOI: 10.3844/ojbsci.2012.34.37

Batista-da-Silva, J.A., G.E. Moya-Borja and M.M.D.C. Queiroz, 2010. Ocorrência e sazonalidade de muscóides (Diptera, Calliphoridae) de importância sanitária no município de itaboraí, RJ, Brasil. Entomobrasilis, 3: 16-21.

BN, 2011. Brazilian Navy.

Cameron, M.E., 1974. The reform movement in China, 1898-1912. 1st Edn., AMS Press, New York, ISBN10: 0404509592, pp: 223.

Carpenter, J.M. and O.M. Marques, 2001. Contribuição ao estudo de os vespídeos do Brasil (Insect, Himenoptera, Vesppoidea, Vespide). Universidade Federal da Bahia, Publicações digitais, 2: 1-147.

Carpenter, J.M., 1981. The phylogenetic relationships and natural classificition of the Vespoidea (Hymenptera). Syst. Entomol., 7: 11-38. DOI: $10.1111 / \mathrm{j} .1365-3113.1982 . t b 00124 . x$

Carpenter, J.M., 2004. Synonymy of the genus marimbonda richards, 1978, With leipomeles möbius, 1856 (hymenoptera: vespidae; polistinae) and a new key to the genera of study wasps of the new world. American Museum of Natural History.
Ferreira, M.J.M., 1978. Sinantropia de dípteros muscóides de Curitiba, Paraná. I: Calliphoridae. Rev. Brasileira Biol., 38: 445-454.

Gallo, D., O. Nakano, S.S Neto, R.P.L. Carvalho and G.C. Batista et al., 1988. Manual De Entomologia Agrícola. 2nd End., Ceres, Piracicaba, ISBN: 8531800013, pp: 531.

Gandaseca, S., N. Rosli, J. Ngayop and C.I. Arianto, 2011. Status of water quality based on the physicochemical assessment on river water at wildlife sanctuary Sibuti mangrove forest, Miri Sarawak. Am. J. Environ. Sci., 7: 269-275. DOI: 10.3844/ajessp.2011.269.275

Henrique-Simoes, M., M.D. Cuozzo and F.A. FrieiroCosta, 2011. Social wasps of unilavras/boqueirão biological reserve, ingaí, state of Minas Gerais, Brazil. Check List, 7: 656-667.

Hermes, M.G. and A. Kohler, 2004. Chave ilustrada para as espécies de vespidae (Insecta, Hymenoptera) ocorrentes no cinturão Verde de Santa Cruz do Sul, RS, Brasil. Caderno Pesquisa Série Biol., 16: 65115.

INPE, 2008. Intituto Nacional de Pesquisas Espaciais.

Johnston, E.L. and M.J. Keough, 2002. Direct and indirect effects of repeated pollution events on marine hard-substrate assemblages. Ecol. Applic., 12: 1212-1228. DOI: 10.2307/3061047

Junior, G.M.T. and F.B. Noll, 2011. Diversity of social wasps on semideciduous seasonal forest fragments with different surrounding matrix in Brazil. Psyche, 2011: 1-8. DOI: $10.1155 / 2011 / 861747$

Kamaruzzaman, B.Y., M.C. Ong, M.S.N.Azhar, S. Shahbudin and K.C.A. Jalal, 2008. Geochemistry of sediment in the major estuarine mangrove forest of terengganu region, Malaysia. Am. J. Applied Sci., 5:1707-1712. DOI: 10.3844/ajassp.2008.1707.1712

Noll, F.B. and B. Gomes, 2009. An improved bait method for collecting hymenoptera, especially social wasps (Vespidae: Polistinae). Neotropical Entomol., 38: 477-481. DOI: 10.1590/S1519566X2009000400006

Santos, G.M.M., C.C.B. Filho, J.J. Resende, J.D. Cruz and O.M. Marques, 2007. Diversity and community structure of social wasps (Hymenoptera: Vespidae) in three ecosystems in Itaparica Island, Bahia State, Brazil. Neotropical Entomol., 36: 180-185. DOI: 10.1590/S1519-566X2007000200002 